\title{
EDUKASI GIZI IBU HAMIL DENGAN MEDIA BOOKLET SEBAGAI UPAYA TINDAKAN PENCEGAHAN STUNTING PADA BALITA DI WILAYAH KERJA PUSKESMAS UNDAAN KABUPATEN KUDUS
}

\author{
Anita Dyah Listyarini ${ }^{1}$, Yayuk Fatmawati ${ }^{2}$,Indriana Savitri ${ }^{3}$ \\ Program Studi IImu Keperawatan STIKES Cendekia Utama Kudus \\ anitadyahlistyarini@gmail.com
}

\begin{abstract}
ABSTRAK
Stunting adalah masalah gizi yang cukup signifikan terkait pertumbuhan dan perkembangan balita. Stunting juga merupakan masalah gizi kronis yang disebabkan oleh asupan gizi kurang dalam waktu yang cukup lama dan disebabkan pemberian makanan tidak sesuai maupun seimbang dengan kebutuhan gizi pada anak. Pemberian pendidikan gizi pada ibu dengan metode booklet dapat memperbaiki tingkat pengetahuan ibu. Media booklet dipilih sebagai media pendidikan kesehatan karena mampu menyebarkan informasi dalam waktu relative singkat, sehingga dapat meningkatkan pengetahuan ibu hamil. Metode pengabdian masyarakat ini adalah obsevasional analitik menggunakan sampel sebanyak 54 ibu hamil trimester I yang tinggal di wilayah kerja Puskesmas Undaan Kabupaten Kudus. Pengabdian masyarakat ini dilakukan pada bulan Juni 2019. Pemilihan sampel dilakukan berdasarkan romdam sampling. Tehnik pengambilan data primer dilakukan melalui wawancara tentang pemenuhan gizi seimbang yang dibutuhkan pada ibu hamil. Hasil kegiatan edukasi pada ibu hamil trimester 1 di wilayah Puskesmas Undaan sebelum diberikan edukasi gizi dengan media booklet mempunyai perubahan pengetahuan dan perilaku perilaku kurang sebanyak $38.8 \%$, cukup $25.9 \%$, dan baik sebanyak $35 \%$ responden, dan setelah dilakukan edukasi gizi menggunakan media booklet responden mempunyai tindakan kurang sebanyak $7.4 \%$ dan cukup $5.5 \%$ dan baik sebanyak $87 \%$.
\end{abstract}

Kata kunci : Edukasi, Booklet, Pencegahan Stunting, Ibu Hamil

\section{ABSTRACT}

Stunting nutrition is a matter a significant and development related children under five years old. Stunting also is a matter of nutrition chronic caused by nutritional intake for lacking in time for quite some time and caused by provision of foog not in accordance and balanced with nutritional requiretment on child. The provisions of education of nutrition in mother with a method of the booklets can improve community knowledge mother. Media booklet chosen as a medium education health capable of spreading information in time relative short. So can increase knowledge pregnant women. A method of the community service activities this is observasional analitytic using samples from 54 pregnant women a trimester I who lives in the work area of Puskesmas Undaan Kabupaten Kudus. The community service activities was being conducted in june 2019. The sampling method of 
sampling was done based on the romdom. Of the receipt of the technique of primary data was done based on the romdam. Of the receipt of the technique of primary data was conducted through interviews abaout nutritional balance required in pregnant women. The results of the education before it was given by the changes have the knowledge and behavior lacking $38.8 \%$, enough $25.9 \%$, and good 35\% it was done using media nutrition education the respondent less $7.4 \%$, enough $5.5 \%$ and $87 \%$.

Keywords : education, booklet, prevention Stunting, Women Pregnant 


\section{PENDAHULUAN}

Balita sangat erat kaitannya dengan pertumbuhan dan perkembangan, masa balita dapat menentukan kesejahteraan suatu bangsa ditunjukkan dengan kesehatan balitanya, karena dimasa yang akan datang anak balita ini yang akan menbangun bangsa sebagai generasi penerus[1]. Dalam menunjang pertumbuhan yang optimal pada balita, dibutuhkan asupan gizi yang seimbang pula. Kebutuhan nutrisi baik anak sangat tinggi hal ini dikarenakan masa pembentukan pertumbuhan dan perkembangan seperti kognitif dan tubuh yang sehat. Sedangkan pemberian nutrisi yang kurang atau buruk di tahun pertama awal pertumbuhannya dapat berdampak pada konsekuensi yang ireversibel, adalah kondisi dimana balita mengalami pertumbuhan terhambat atau stunting [2].

Stunting adalah masalah gizi yang cukup signifikan terkait pertumbuhan dan perkembangan balita. Stunting juga merupakan masalah gizi kronis yang disebabkan oleh asupan gizi kurang dalam waktu yang cukup lama dan disebabkan pemberian makanan tidak sesuai maupun seimbang dengan kebutuhan gizi pada anak. Stunting dapat terjadi ketika anak masih dalam kandungan dan baru kelihatan saat anak berusia dua tahun. Kekurangan gizi pada anak usia dini meningkatkan angka kematian bayi dan anak, mudah sakit dan memiliki postur tubuh kurang ideal saat dewasa, kemampuan kognitif kurang, sehingga mengakibatkan penurunan kesejahteraan jangka panjang bagi bangsa [2]. Masalah stanting tersebut memiliki faktor penyebab, diantaranya gizi yang kurang, kondisi ibu yang kurang nutrisi di masa remajanya dan masa kehamilan, pada masa menyusui, dan infeksi pada ibu. Faktor lainnya berupa kualitas pangan dan rendahnya asupan vitamin dan mineral, kurangnya makanan sumber protein tinggi yang sangat dibutuhkan oleh tubuh.

Keadaan stunting atau balita yang bertubuh pendek merupakan indikator masalah gizi dari keadaan yang berlangsung lama. Balita 
stunting selain mengalami gangguan pertumbuhan umumnya memiliki kecerdasan yang lebih rendah dari anak balita normal. Selain itu anak stunting akan lebih rentan menderita penyakit tidak menular, ketika dewasa nanti mengalami produktifitas kerja yang rendah, sehingga mencegah dan mengatasi stunting akan meningkatkan kualitas hidup di masa depan.

Edukasi merupakan bagian kegiatan pendidikan kesehatan. Pendidikan kesehatan didefinisikan sebagai proses pembelajaran yang dilakukan kepada individu, keluarga, kelompok, dan masyarakat yang dilakukan dengan tujuan untuk merubah perilaku yang tidak sehat ke pola yang lebih sehat. Proses pendidikan kesehatan melibatkan beberapa komponen, antara lain menggunakan strategi belajar mengajar, mempertahankan keputusan untuk membuat perubahan tindakan/perilaku, dan pendidikan kesehatan juga berfokus kepada perubahan perilaku untuk meningkatkan status kesehatan mereka[2].

Berdasarkan hasil penelitian Setyawati dkk. menunjukan bahwa pendidikan kesehatan tentang gizi menggunakan booklet pada ibu dapat meningkatkan pengetahuan ibu hamil. Hal ini juga didukung oleh Zulaekah yang menunjukan bahwa pemberian pendidikan gizi pada ibu dengan metode booklet dapat memperbaiki tingkat pengetahuan ibu.

Media booklet dipilih sebagai media pendidikan kesehatan karena mampu menyebarkan informasi dalam waktu relative singkat, sehingga dapat meningkatkan pengetahuan ibu hamil.

Ibu dengan pengetahuan gizi yang baik kemungkinan akan memberikan gizi yang cukup pada bayinya. Apabila seorang ibu memiliki pengetahuan yang baik maka ibu tersebut akan berusaha untuk memenuhi kebutuhan gizinya dan juga bayinya Pengetahuan ibu hamil tentang gizi akan mempengaruhi dalam pengambilan keputusan dan juga akan berpengaruh pada perilaku ibu [4].

Perilaku merupakan suatu respons seeorang terhadap stimulus yang berkaitan dengan sakit dan penyakit, system pelayanan kesehatan, 
makanan serta lingkungan. Batasan ini mempunyai dua unsur pokok, yakni responsdan stimulus atau perangsangan. Respon atau reaksi manusia, baik bersifat pasif (pengetahuan, persepsi, sikap) maupun bersifat aktif (tindakan yang nyata atau practice), sedangkan stimulus atau rangsangan di sini terdiri dari empat unsur pokok yakni skaitdan penyakit, system pelayanan kesehatan dan lingkungan.

Pengetahuan mengenai gizi, merupakan suatu proses awal yang menentukan perubahan perilaku mengenai peningkatan status gizi, sehingga pengetahuan merupakan factor internal yang mempengaruhi perubahan perilaku. Pengetahuan ibu tentang gizi akan menentukan perilaku ibu dalam menyediakan makanan untuk keluarga. Ibu dengan pengetahuan gizi yang baik dapat menyediakan makanan dengan jenis dan jumlah yang tepat untuk mendukung pertumbuhan dan perkembangan anaknya. Pengetahuan ibu tentang tentang gizi merupakan salah satu factor penyebab stunting pada anak[2]

Berdasarkan Riskesdas tahun 2017 di Indonesia sekitar 37, 2\% (hampir 9 juta) anak balita mengalami stunting dan di seluruh dunia, Indonesia adalah negara dengan prevalensi stuntingkelima terbesar4. Kemudian berdasarkan data Kemenkes 2016 prevalensi stunting di Indonesia mencapai $37,2 \%$ artinya satu dari tiga anak di Indonesia mengalami stunting sedangkan di Jawa Tengah prevalensi stunting sebesar $28 \%$. Salah satu prioritas pembangunan kesehatan Indonesia dalam Rencana Pembangunan Jangka Menengah Nasional (RPJM) tahun 2015-2019 adalah perbaikan gizi khususnya stunting.

Berdasarkan Studi Pendahuluan yang dilakukan oleh peneliti yang dilakukan di Puskesmas Undaan pada bulan Januari 2018, didapatkan data bahwa Kejadian stunting di wilayah Kabupaten Kudus tertinggi adalah di Kecamatan Undaan. Pada tahun 2017 balita stunting di wilayah puskesamas Undaan dengan jumlah total balita stunting sebesar 596, dimana laki laki sebanyak 327 dan perempuan sebanyak 269 . Sedangkan pada tahun 2018 balita stunting berjumlah 542 dengan jumlah laki laki 300 
dan perempuan 242. Lokasi tersebut adalah di Desa Medini dengan 8 posyandu, Kalirejo dengan 6 posyandu, Teramas 3 posyandu, Lambangan 3 posyandu, Wonosoco 2 posyandu, Kutuk 5 posyandu, Undaan Kidul 5 posyandu, Benjang 2 posyandu, Sambung 5 posyandu, dan Desa Glagah ada 5 Posyandu .

Prevalensi stunting di Desa Undaan tahun 2017 mencapai >20\% dan di Tahun 2018 mencapai $>17 \%$. Hal ini menunjukan bahwa masalah stunting di Wilayah Puskesmas Undaan di Kabupaten Kudus masih menjadi masalah kesehatan prioritas di Wilayah Puskesmas Undaan Kabupaten Kudus.

Jumlah ibu hamil Trimester I yang memeriksakan kehamilan di Puskesmas Undaan pada bulan April 2019 adalah sebanyak 54 ibu hamil, yaitu di Desa Undaan Kidul adalah sebanyak 6, Desa Sambung adalah 8, Medini 11, Kalirejo 5, Lambangan 7, Kutuk 4, , Teramas 10, Wonosoco 1, dan Beru Genjang sebanyak 2 ibu hamil yang seluruhnya adalah menjadi responden dalam penelitian ini.

Ibu Hamil di wilayah kerja Puskesmas Undaan, sekitar 10 - 15 ibu hamil setiap hari datang memeriksakan kehamilannya di puskesmas. Pelayanan bidan pada program posyandu di setiap dusun di Undaan kurang dimanfaatkan dengan baik oleh sebagian besar ibu hamil yang dapat mengakibatkan kurangnya informasi yang diperoleh bagi calon ibu dan sesuai yang ditinjau oleh peneliti, ada yang belum terlalu memahami tentang pemenuhan gizi yang tepat selama kehamilan seperti hanya mengetahui 4 sehat 5 sempurna saja.

Berdasarkan uraian latar belakang masalah diatas, maka perlu dilakukan pengabdian masyarakat Edukasi Gizi lbu Hamil dengan Media Booklet terhadap Perilaku Pencegahan Balita Stunting di Wilayah Puskesmas Undaan Kabupaten Kudus. 


\section{METODE PELAKSANAAN}

Metode yang digunakan dalam pengabdian masyarakat ini adalah obsevasional analitik menggunakan sampel sebanyak 54 ibu hamil trimester I yang tinggal di wilayah kerja Puskesmas Undaan Kabupaten Kudus. Pengabdian ini dilakukan pada bulan Juni 2019. Pemilihan sampel dilakukan berdasarkan romdam sampling. Tehnik pengambilan data primer dilakukan melalui wawancara tentang pemenuhan gizi seimbang yang dibutuhkan pada ibu hamil.

Edukasi dapat menggunakan berbagai media. Media dalam penyuluhan kesehatan dapat diartikan sebagai alat bantu promosi kesehatan untuk memperlancar komunikasi dan penyebarluasan informasi, Media yang digunakan dalam pengabdian masyarakat ini adalah booklet. Bokklet adalah cetakan dengan tampilan istimewa berbentuk buku. Boklet dapat dipakai untuk menunjukan contoh-contoh karya cipta yang berhubungan dengan produk [4].

Pengembangan booklet adalah kebutuhan untuk menyediakan referensi (bahan bacaan) bagi kelompok masyarakat yang memiliki keterbatasan akses terhadap buku sumber karena keterbatasan mereka. Dengan adanya booklet masyarakat dapat memperoleh pengetahuan seperti membaca buku, dengan waktu membaca yang singkat, dan dalam keadaan apapun.

\section{HASIL DAN PEMBAHASAN}

Pengabdian masyarakat ini dilakukan di Wilayah Puskesmas Undaan Keamataan Undaan Kabupaten Kudus. Dimana Puskesmas Undaan Mencakup Desa Undaan Kidul,Desa Sambung, Desa Medini, Desa Kalirejo, Lambangan, Kutuk, Terangmas, Wonosoco dan Beru Genjang.

Beberapa posyandu yang mencakup Puskesmas Undaan diantaranya adalah di Desa Medini dengan 8 posyandu, Kalirejo dengan 6 posyandu, Teramas 3 posyandu, Lambangan 3 posyandu, Wonosoco 2 posyandu, Kutuk 5 posyandu, Undaan Kidul 5 posyandu, Benjang 2 
posyandu, Sambung 5 posyandu, dan Desa Glagah ada 5 Posyandu. Responden yang menjadi subjek penelitian ini adalah sebanyak 54 responden yang telah memenuhi kriteria dalam penelitian ini. Hasil penelitian meliputi karakteristik responden, perilaku sebeleum dan sesudah edukasi dengan media booklet serta analisa perbedaan perilaku antara sebelum dan setelah diberikan edukasi gizi dengan menggunakan media booklet.

Sasaran pada pengabdian masyarakat ini ini adalah lbu Hamil Trimester1di Wilayah Puskesmas Undaan Kabupaaten Kudus. Dalam pengabdian masyarakat ini sampel berjumlah 54 responden.

Hasil Perubahan Pengetahuan dan Perilaku Pencegahan Stunting pada balita oleh ibu hamil Trimester I tentang Pemenuhan gizi di Wilayah Puskesmas Undaaan Kabupaten kudus, dijabarkan dalam table berikut :

\begin{tabular}{lcccc}
\hline $\begin{array}{l}\text { Pengetahuan } \\
\text { Perilaku }\end{array}$ & \multicolumn{2}{c}{ Sebelum } & \multicolumn{2}{c}{ Sesudah } \\
\hline & Frekuensi & Persentase (\%) & Frekuensi & Persentase (\%) \\
\hline Kurang & 21 & 38.8 & 4 & 7.4 \\
Cukup & 14 & 25.9 & 3 & 5.5 \\
Baik & 19 & 35 & 47 & 87 \\
Total & 54 & 100 & 54 & 100 \\
& & & & \\
\hline
\end{tabular}

Berdasarkan Tabel tersebut diketahui bahwa hasil kegiatan edukasi pada ibu hamil trimester 1 di wilayah Puskesmas Undaan sebelum diberikan edukasi gizi dengan media booklet mempunyai perubahan pengetahuan dan perilaku perilaku kurang sebanyak 21(38.8\%), cukup 14(25.9\%), dan baik sebanyak 19 (35\%) responden, dan setelah dilakukan edukasi gizi mengguunakan media booklet responden mempunyai tindakan kurang sebanyak 4 (7.4\%) dan cukup 3 (5.5\%) dan baik sebanyak $47(87 \%)$. 

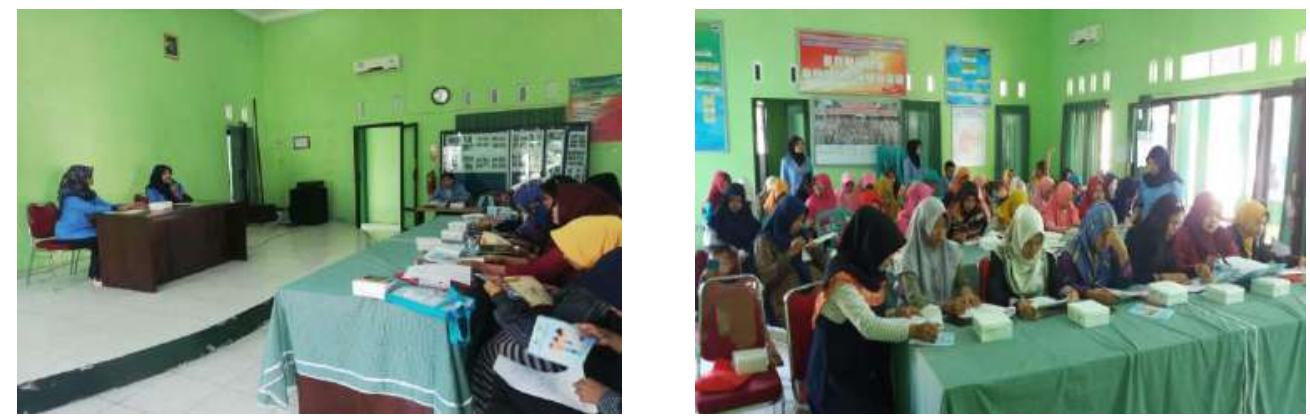

Gambar 1 : edukasi gizi lbu hamil di wilayah Puskesmas Undaan

Hasil penelitian menunjukan bahwa dengan pendidikan gizi menggunakan media booklet pada ibu dapat meningkatkan pengetahuan ibu mengenai gizi. Booklet memiliki dua kelebihan dibandingkan dengan media lain yaitu dapat dipelajari setiap saat karena didesain dalam bentuk buku serta memuat informasi lebih banyak (Roza, 2012). Media booklet dipilih sebagai media pendidikan kesehatan karena mampu menyebarkan informasi dalam waktu relative singkat, sehingga dapat meningkatkan pengetahuan ibu hamil. Hal ini dibuktikan dengan peneliian Sumaryati (2003) bahwa terdapat perbedaan signifikan pada pengetahuan siswi tentang anemia sebelum dan sesudah diberikan intervensi dengan media booklet. Booklet akan memberikan kesan kepada pembaca jika disajikan dengan gambar yang menarik sehingga booklet tidak formal dan kaku[5]. Kurangnya pendidikan, pengalaman dan informasi tentang pendidikan kesehatan juga dapat mempengaruhi pengetahuan ibu hamil . Pendidikan kesehatan sangat penting untuk meningkatan derajat kesehatan. Dengan adanya pendidikan dapat merubah perilaku seseorang, pola hidup, serta meningkatkan motivasi untuk meningkatkan kesehatan ligkungan [6].

\section{SIMPULAN DAN SARAN}

Kegiatan pengabdian masyarakat ini berupa Edukasi Gizi lbu Hamil dengan Media Booklet terhadap Perilaku Pencegahan Balita Stunting di Wilayah Puskesmas Undaan Kabupaten Kudus sebagai upaya pencegahan terjadinya stunting pada balita di daerah kecamatan undaan. Pendidikan kesehatan dilakukan dengan pemberian booklet tentang gizi 
seimbang untuk ibu hamil, diharapkan dengan pemberian booklet pada ibu hamil ini, ibu hamil dapat dengan sadar melakukan tindakan pemenuhan gizi pada saat kehamilan trimester I, 2 dan 3, sehingga stunting pada balita dapat dicegah.

Upaya peningkatan pengetahuan yang merupakan bagian dari perilaku pencegahan stunting dengan sasaran ibu hamil diharapkan mampu menjaga gizi yang optimal pada balita dari sebelum dilahirkan sampai dengan kehidupan selanjutnya sehingga tidak mengalami kekurangan gizi. Pencegahan stunting dengan sasaran ibu hamil bertujuan untuk memperbaiki giizi dan kesehatan ibu hamil merupakan cara terbaik dalam mengatasi stunting. Ibu hamil perlu mendapat makanan yang baik, sehingga apabila ibu hamil mengalami kurang energi kronis (KEK) perlu diberikan makanan tambahan bagi ibu hamil

\section{UCAPAN TERIMAKASIH}

1. Program Pengabdian masyarakat ini dibiayai oleh STIKES Cendekia Utama Kudus dengan Surat Perjanjian Kontrak Pengabdian Masyarakat (SPK-PM) Nomor: 027/SK-PI/LPPM-STIKES CU/V/2019 Tanggal 15 Mei 2019

2. Kepala Puskesmas Undaan Kabupaten Kudus bapak dr. Edi Kusworo yang telah memberikan ijin sehingga program pengabdian masyarakat ini berjalan dengan baik dan lancar.

\section{DAFTAR PUSTAKA}

1. Kepmenkes RI. Profil kesehatan indonesia. Jakarta: Kementrian Kesehatan Republik Indonesia. 2016

2. Devi M. Analisis faktor-faktor yang berpengaruh terhadap status gizi balita di pedesaan. Teknologi dan Kejuruan. 2012 Aug 24;33(2)

3. Anugraheni HS, Kartasurya MI. Faktor risiko kejadian stunting pada anak usia 12-36 bulan di Kecamatan Pati, Kabupaten Pati (Doctoral dissertation, Diponegoro University) 
4. Riskesdas (2013) Riset Kesehatan Dasar Tahun 2013 . Jakarta: Badan Penelitian Dan Pengembangan Kesehatan Kementrian Kesehatan RI

5. Profil Kesehatan Jawa Tengah (2017)

6. Profil Kesehatan Kabupaten Kudus (2018)

7. Profil Kesehatan Wilayah Kerja Puskesmas Undaan Kabupaten Kudus

8. Kementrian desa, Pembangunan Daerah Tertinggal dan Transmigrasi. Buku Saku Desa dalam Penanganan Stunting (2017)

9. Sekretariat Wakil Presiden Republik Indonesia , 100 Kabupaten/Kota Prioritas untuk intervensi anak kerdil (Stunting) Ringkasan, .Tim Nasional Percepatan Penanggulangan Kemiskinan. Cetakan Pertama,(2017). 